\title{
PENGOLAHAN LIMBAH LAUNDRY MENGGUNAKAN METODE BIOSAND FILTER UNTUK MENDEGRADASI FOSFAT
}

\author{
Sri Widya Astuti, Mersi Suriani Sinaga \\ Departemen Teknik Kimia, Fakultas Teknik, Universitas Sumatera Utara, \\ Jl. Almamater Kampus USU Medan 20155, Indonesia \\ Email : sriwidya_sinurat@yahoo.com
}

\begin{abstract}
Abstrak
Limbah laundry dominan berasal dari pelembut pakaian dan deterjen yang merupakan bahan tidak ramah lingkungan (non-biodegraduble) sehingga harus dilakukan pengolahan sebelum dibuang ke badan air. Bahan baku yang digunakan adalah limbah laundry. Penelitian ini bertujuan untuk mengurangi kandungan fosfat dan surfaktan dengan metode biosand filter yang menggunakan adsorben karbon aktif dengan perbandingan campuran limbah laundry dan nutrisi yaitu 100\%:0, 75\%:25\%, dan 50\%:50\% (dalam \% volume) dengan proses anaerobik. Parameter yang dianalisis adalah Chemical Oxygen Demand (COD), Total Suspended Solid (TSS), Volatile Suspended Solid (VSS), pH disetiap hari serta Fosfat dan Surfaktan sebelum dan sesudah mengalami proses anaerobik. $\mathrm{pH}$ untuk penelitian ini diatur pada kisaran 6,9-7,5. Volume terbesar pada rasio 50\%:50\% (v/v) campuran limbah laundry dan nutrisi diperoleh persentase TSS sebesar 76,61\%, persentase VSS sebesar $63,55 \%$, persentase COD sebesar 53,67 \%, persentase fosfat sebesar 74,32 \% dan surfaktan sebesar 53,54\%. Pengurangan nilai fosfat dan surfaktan diakibatkan adanya lapisan kotor (biofilm) dalam tangki sehingga menghasilkan fosfat dan surfaktan yang telah memenuhi baku mutu berdasarkan Peraturan Pemerintah Republik Indonesia No. 82 Tahun 2001.
\end{abstract}

Kata kunci : Biofilm, Biosand Filter, Fosfat, Laundry, VSS

\begin{abstract}
Laundry waste dominant comes from clothes softener and detergent which is one of the environmentally inhospitable material (non-biodegraduble) soit has to be processed before dumped into the waste. The basic material that use in this research is waste laundry. The purpose of this research is to decrease phosphate and surfactant content by biosand filter method which using active carbon adsorbent with ratio of mixed waste laundry and nutrition is 100\%:0, 75\%:25\%, and 50\%:50\% (in \% volume) by anaerobic process. The parameter that being analyzed are Chemical Oxygen Demand (COD), Total Suspended Solid (TSS), Volatile Suspended Solid (VSS), daily $\mathrm{pH}$ also Phosphate and Surfactant before and after being processed anaerobically. $\mathrm{pH}$ for this research arranged in range 6,9-7,5. The largest volume in VSS ratio is $63,55 \%$, COD percentage is $53,67 \%$, phosphate percentage is $74,32 \%$, and surfactant is $53,54 \%$. The reduction of phosphate and surfactant value result by the present of contaminate layer (biofilm) in tank so that produce phosphate and surfactant that have been fill quality based on government regulation of the Republic Indonesia No. 82 of 2001.
\end{abstract}

Keywords : Biofilm, Biosand Filter, Phosphates, Laundry, VSS

\section{Pendahuluan}

Pemakaian deterjen semakin lama semakin meningkat sejalan dengan laju pertumbuhan penduduk setiap tahun, artinya semakin meningkat pendapatan masyarakat maka konsumsi deterjen juga meningkat. Dampak yang ditimbulkan bila air buangan yang mengandung deterjen berlebihan adalah terjadinya pencemaran dan menggangu ekosistem biota yang terdapat diperairan. Limbah laundry dominan berasal dari pelembut pakaian dan deterjen. Bahan aktif yang banyak terkandung pada pelembut pakaian dan deterjen adalah ammonium klorida, LAS, sodium dodecyl benzene sulfonate, natrium karbonat, natrium sulfat, alkilbenzena sulfonate. Bahan-bahan tersebut merupakan bahan yang tidak ramah lingkungan (non-biodegraduble)[5].

Di Indonesia belum banyak upaya khusus untuk menangani masalah pencemaran air yang disebabkan oleh deterjen. Beberapa upaya yang telah dilakukan salah satunya dengan mengganti rantai bercabang dari Alkyl Benzen Sulfonate (ABS) menjadi rantai lurus Linier Alkyl Sulfonate (LAS) yang dapat dibiodegradasi. Deterjen ini bersifat dapat dirusak oleh mikroorganisme [11].

Penggunaan deterjen yang semakin meningkat ini akan berdampak negatif terhadap akumulasi surfaktan pada bahan-bahan perairan sehingga menimbulkan masalah pendangkalan perairan, terhambatnya transfer oksigen dan lainlain. Pada kondisi aerob LAS dapat terdegradasi dengan baik, namun jika dalam keadaan anaerob penyisihan LAS masih kurang baik [8].

Penanganan lain yang telah dilakukan untuk menangani masalah pencemaran yang disebabkan oleh limbah laundry adalah metode Biosand Filter. Biosand Filter merupakan filter dengan konsep saringan pasir lambat yang khusus didesain untuk skala rumah tangga. Kelebihan biosand filter adalah adanya penumbuhan biofilm dipermukaan 
media paling atas yang mampu mendegradasi rasa, bau dan warna. Biosand Filter menggunakan media pasir halus, pasir kasar dan kerikil dan adanya penambahan mikroorganisme sebagai pembantu dalam menurunkan kandungan organik dalam limbah laundry. Penambahan karbon aktif berfungsi untuk meningkatkan efesiensi dalam menurunkan kadar bahan-bahan organik dan untuk menurunkan konsentrasi surfaktan yang terlarut dalam limbah laundry sebelum dibuang kelingkungan perairan yang sebelumnya metode ini hanya digunakan untuk pengolahan air minum saja [6].

Tujuan dari penelitian ini adalah mengurangi kandungan fosfat dan surfaktan dengan metode biosand filter dengan menggunakan adsorben karbon aktif.

\section{Teori}

Berdasarkan Peraturan Pemerintah Republik Indonesia No. 82 Tahun 2001 tentang baku mutu air limbah domestik, air limbah domestik adalah air limbah yang berasal dari usaha dan atau kegiatan permukaan (real state), rumah makan, perkantoran, perniagaan, apartemen dan asrama [10].

Limbah cair domestik terbagi dalam dua kategori yaitu limbah cair domestik yang berasal dari air cucian, seperti sabun, detejen, minyak dan peptisida dan limbah cair domestik yang berasal dari kakus, seperti sabun, shampoo, tinja dan air seni [18]. Maka dapat disimpulkan limbah laundry termasuk kedalam kategori limbah cair domestik. Usaha laundry dalam prosesnya menggunakan deterjen dan sabun sebagai bahan pencuci. Akan tetapi deterjen lebih sering digunakan daripada sabun karena deterjen dapat menghasilkan buih yang lebih banyak dibandingkan dengan sabun yang menurut kebanyakan orang banyaknya buih mampu menghilangkan kotoran yang berada di pakaian mereka.

Limbah cair laundry yang dihasilkan oleh deterjen mengandung fosfat yang tinggi yang berasal dari sodium tripolyphospat (STPP) yang dalam deterjen berfungsi sebagai builder yang merupakan unsur terpenting kedua setelah surfaktan karena kemampuannya menonaktifkan mineral kesadahan dalam air sehingga deterjen dapat bekerja secara optimal [3].

Bila kandungan fosfat dalam air limbah laundry semakin tinggi maka hal ini akan mengganggu lingkungan sekitar badan air. Antara lain yaitu menyebabkan eutrofikasi dimana badan air menjadi kaya akan nutrien terlarut, menurunnya kandungan oksigen terlarut dan kemampuan daya dukung badan air terhadap biota air [5].

Biosand Filter (BSF) merupakan pengembangan dari slow sand filter dimana BSF juga melalui proses yang sama dengan saringan pasir lambat, yaitu dengan cara melewati pasir dalam filter [17].

BSF didesain $5 \mathrm{~cm}$ di bagian atas air lapisan pasir halus karena ketinggian tersebut merupakan ketinggian yang optimum dari perpindahan patogen. Jika tingkatan air terlalu dangkal, lapisan biofilm dapat lebih mudah terganggu karena rusak oleh kecepatan datangnya air. Di sisi lain, jika tingkatan air terlalu dalam maka jumlahnya tidak cukup pada difusi $\mathrm{O}_{2}$ pada biofilm, sehingga mengakibatkan kematian dari mikrooragnisme pada lapisan biofilm. Ketika air yang terkontaminasi mikroorganisme dimurnikan dengan BSF, organisme pemangsa yang berada di lapisan biofilm akan memakan patogen-patogen yang ada [9].

Menurut Sukawati (2008), lapisan biofilm terdiri dari sel-sel mikroorganisme yang melekat erat ke suatu permukaan sehingga berada dalam keadaan diam, tidak mudah lepas atau berpindah tempat (irreversible). Biasanya lapisan biofilm ini digunakan untuk menandakan zona aktivitas biologi yang umumnya terjadi di dalam bed pasir.

BSF sangat mirip dengan saringan pasir lambat dalam arti bahwa mayoritas dari filtrasi dan kepindahan kekeruhan terjadi di puncak lapisan pasir dalam kaitan dengan ukuran pori-pori yang menurun disebabkan oleh penguraian partikel butir. Teknologi ini dapat mencapai 99,99\% penghilang virus tipus. Keuntungan teknologi ini selain murah, membutuhkan sedikit pemeliharaan dan beroperasi secara gravitasi [7].

Karbon aktif merupakan suatu bahan yang berupa karbon amorf yang sebagian besar terdiri dari karbon bebas serta mempunyai kemampuan daya jerap (adsorpsi) yang baik. Activated carbon digunakan sebagai bahan pemucat (penghilang zat warna), penjerap gas, penjerap logam, dan sebagainya. Dari bahan tersebut yang paling sering dipergunakan sebagai bahan adsorben adalah activated carbon [12]. Sifat activated carbon yang paling penting adalah daya jerap. Penjerapan secara umum adalah proses mengumpulkan benda-benda terlarut yang terdapat di dalam larutan antara dua permukaan. Antar permukaan itu dapat berupa cairan dan gas, cairan dan padatan. Bahan penjerapan yang digunakan pada permukaan adalah zat padat dan zat yang kental [16].

\section{Metodologi Penelitian \\ Bahan dan Alat}

Bahan utama yang digunakan adalah limbah cair laundry, sebagai bahan pembantu, digunakan molase dan digunakan adsorben sebagai adsorben yang dicampur dengan air masing-masing variasi perbandingan 100\%:0, 75\%:25\% dan 50\%:50\% dari volume tangki terisi $(8 \mathrm{~L})$. Alat utama yang 
digunakan adalah biosand filter untuk proses seeding dan karbon aktif untuk proses adsorspi.

\section{Proses Pengurangan Fosfat Pada Limbah Laundry}

Dalam penelitian ini bahan baku yang digunakan adalah Limbah Cair Laundry dan bahan tambahan lainnya yaitu Molase dan Urea sebagai sumber nutrisi saat proses aklimatisasi. Sebelum dilakukan proses penjernihan limbah cair laundry menggunakan tangki biosand filter dan tangki karbon aktif, dilakukan analisis limbah cair laundry terlebih dahulu yaitu analisis Fosfat, Surfaktan, pH, COD (Chemical Oxygen Demand), TSS (Total Suspended Solid), dan VSS (Volatil Suspended Solid). Setelah dilakukan analisis awal, limbah cair laundry kemudian dimasukkan ke dalam tangki yang memiliki volume $8 \mathrm{~L}$ dengan perbandingan variasi komposisi limbah cair laundry : nutrisi adalah 100\%:0; 75\%:25\%; dan 50\%:50\% (dalam \% volume). Kemudian dilakukan proses aklimatisasi (proses pertumbuhan mikroba) dengan penjagaan $\mathrm{pH}$ dan dilakukan analisa COD, TSS dan VSS pada tangki dengan masing-masing perbandingan di dalam tangki biosand filter. Analisis dihentikan setelah nilai TSS dan VSS yang didapat menjadi konstan, air limbah laundry kemudian dilanjutkan masuk ke dalam tangki yang berisikan karbon aktif atau disebut tangki karbon aktif.

\section{Penentuan Konsentrasi Volatile Suspended Solid (VSS)}

VSS merupakan besarnya bahan organik dari TSS yang dihilangkan melalui pembakaran di dalam furnance dengan suhu $550{ }^{\circ} \mathrm{C}$ selama 2 jam dan penghitungan kadar abu. Fosfat dalam air limbah dapat berupa fosfat organik, orthophosphate anorganik atau sebagai fosfat kompleks. Fosfat organik terdapat didalam air buangan dan sisa makanan. Fosfat organik juga dapat berasal dari bakteri atau tumbuhan penyerap fosfat. Fosfat kompleks mewakili kurang lebih separuh dari fosfat limbah perkotaan dan berasal dari penggunaan deterjen sintetis [4]. Kadar VSS dapat dihitung dengan persamaan 1 .

mg padatan volatil tersuspensi $/ \mathrm{L}=\frac{(\mathrm{A}-\mathrm{B}) \times 1000}{\operatorname{volume} \operatorname{sampel}(\mathrm{mL})} \ldots(1)$

Dimana:

$\mathrm{A}=$ berat residu yang tertahan diatas kertas saring kering + cawan porselen,mg

$\mathrm{B}=$ berat cawan porselen $+\mathrm{abu}, \mathrm{mg}$

\section{Hasil dan Pembahasan}

\section{Profil pH pada Tangki Biosand Filter}

$\mathrm{pH}$ merupakan parameter yang sangat penting dalam menentukan kondisi kehidupan mikroba di dalam tangki selama fermentasi anaerobik berlangsung dan merupakan faktor yang sangat mempengaruhi pertumbuhan mikroorganisme dalam degradasi organik secara anaerob [14].

Pengaruh waktu aklimatisasi terhadap $\mathrm{pH}$ pada tangki biosand filter dapat dilihat pada gambar 1.

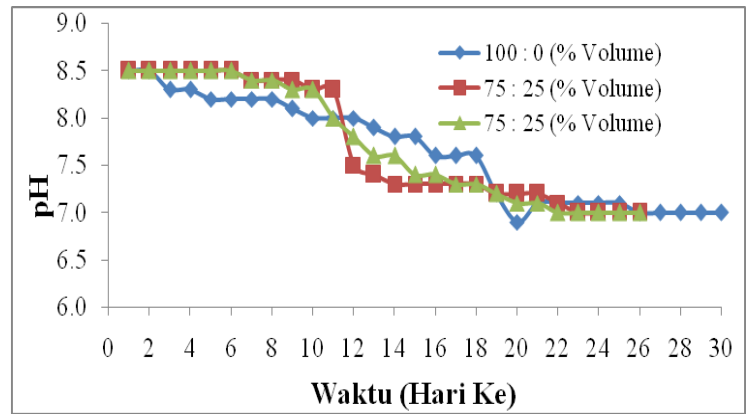

\section{Gambar 1. Pengaruh Waktu terhadap pH pada Tangki Biosand Filter}

Dari gambar 1 dapat dilihat, nilai $\mathrm{pH}$ berfluktuasi pada setiap sampel limbah cair laundry dengan nutrisi yakni pada variasi perbandingan 100\%:0, 75\%:25\%, dan 50\%:50\% (dalam $\%$ volume) dari hari ke-1 sampai \pm hari ke30. Nilai $\mathrm{pH}$ yang paling berfluktuasi dengan rentang $\mathrm{pH}$ 8,3-7,5 yaitu pada perbandingan 75\%:25\% di hari ke-14, pada perbandingan 100\%:0 mengalami fluktuasi dengan rentang $\mathrm{pH}$ 7,6-6,9 di hari ke-22 begitu juga untuk perbandingan 50\%:50\% dengan rentang $\mathrm{pH}$ $8,0=7,8$ di hari ke- 15 .

Penurunan nilai $\mathrm{pH}$ pada limbah yang memiliki kandungan deterjen menandakan terjadinya biodegradasi LAS (Linier Alkyl Sulfonate) [15]. Hal ini juga dapat dipengaruhi adanya penambahan larutan urea yang diberikan sebagai sumber nutrisi mikroorganisme dalam menumbuhkan lapisan biofilm sehingga $\mathrm{pH}$ air menjadi basa [19].

\section{Profil Chemical Oxygen Demand (COD) pada Tangki Biosand Filter}

Selain $\mathrm{pH}$ yang merupakan parameter dalam penentuan ada tidaknya mikroba yang tumbuh pada tangki BSF, COD juga merupakan parameter yang penting dalam menentukan kondisi kehidupan mikroba di dalam tangki BSF selama mengalami proses fermentasi anaerobik berlangsung karena COD (Chemical Oxygen Demand) merupakan jumlah total oksigen yang dibutuhkan untuk mengoksidasi bahan organik secara kimiawi, baik yang dapat didegradasi secara biologis maupun yang sukar didegradasi secara biologis menjadi $\mathrm{CO}_{2}$ dan $\mathrm{H}_{2} \mathrm{O}$ [13].

Pengaruh waktu aklimatisasi terhadap nilai COD pada tangki biosand filter dapat dilihat pada gambar 2. 


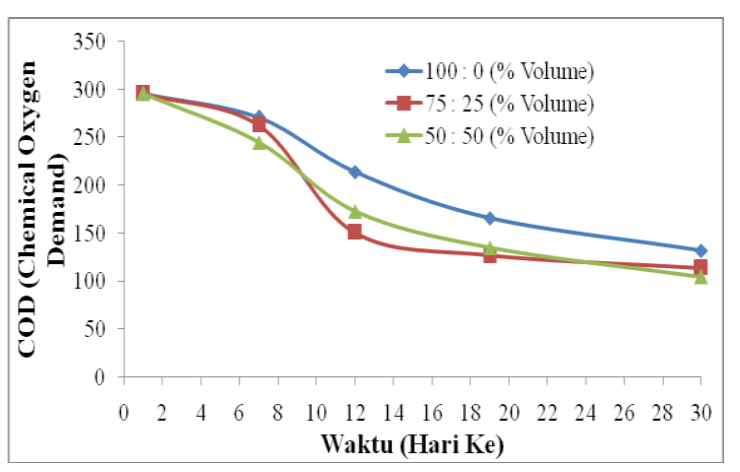

Gambar 2. Pengaruh Waktu Terhadap COD pada Tangki Biosand Filter

Dari gambar 2 dapat dilihat, degradasi COD pada biosand filter terhadap waktu pada variasi perbandingan antara limbah cair laundry dengan nutrisi yaitu 100\%:0, 75\%:25\% dan 50\%:50\% (dalam \% volume) dari hari ke-1 sampai hari ke30. COD yang paling mengalami degradasi adalah pada variasi perbandingan 50\%:50\% yakni nilai COD awal $296 \mathrm{mg} / \mathrm{l}$ menjadi $105 \mathrm{mg} / \mathrm{l}$ di hari ke26 , pada perbandingan $75 \% /: 25 \%$ mengalami degradasi yakni $296 \mathrm{mg} / \mathrm{l}$ menjadi $114 \mathrm{mg} / \mathrm{l}$ di hari ke-26 begitu juga pada perbandingan 100\%:0 mengalami degradasi yakni $296 \mathrm{mg} / \mathrm{l}$ di awal menjadi 132 mg/l di hari ke-26.

Dari hasil penelitian dapat dilihat bahwa tinggi pasir yang digunakan sebagai variabel untuk pengukuran COD berpengaruh terhadap penurunan COD. Semakin tinggi pasir yang digunakan maka akan semakin besar penurunan CODnya. Hal ini disebabkan karena mikroba yang terdapat dalam air limbah mengalami kontak yang cukup lama dengan media biofilter pasir sehingga mempengaruhi penurunan CODnya. Jika semakin tinggi pasir yang digunakan maka waktu kontak antara mikroba dengan pasir dan air limbah menjadi semakin lama karena limbah akan sering mengalami sirkulasi. Hal ini mengakibatkan penurunan COD menjadi semakin besar [1].

Penurunan yang disebabkan oleh mikroba ini terjadi apabila lapisan biofilm sudah mengalami pengelupasan karena ketebalan dari biofilm sudah maksimal. Pada kondisi ini sumber makanan tidak bias terdifusi sampai lapisan paling dalam oleh mikroorganisme memasuki fase endugeus yaitu fase dimana bakteri akan kehilangan kemampuan menempel pada media sehingga akan terlepas dan terbawa keluar oleh biofilter yang disebabkan air yang terlewati [4].

\section{Profil Volatile Suspended Solid (VSS) pada Tangki Biosand Filter}

Volatile suspended solid (VSS) merupakan besarnya bahan organik dari padatan tersuspensi (TSS) yang dihilangkan melalui pembakaran di dalam furnance dengan suhu $550{ }^{0} \mathrm{C}$ selama 2 jam dan penghitungan kadar abu.

Pengaruh waktu aklimatisasi terhadap nilai volatile suspended solid (VSS) pada tangki biosand filter dapat dilihat pada gambar 3 .

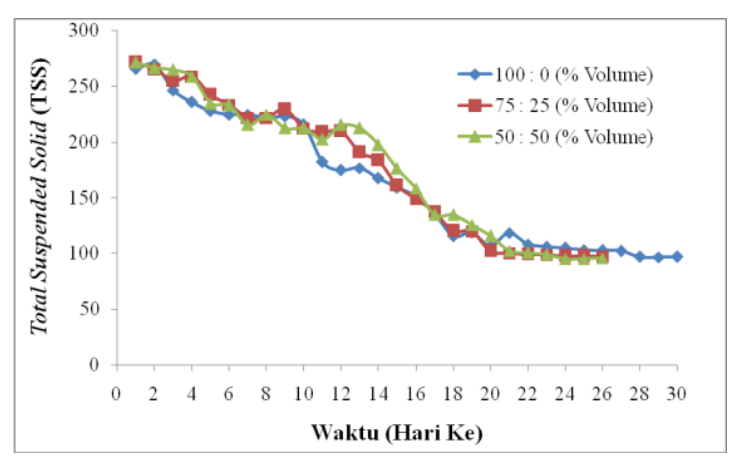

\section{Gambar 3. Pengaruh Waktu Terhadap Volatile Suspended Solid pada Biosand Filter}

Dari gambar 3 dapat dilihat, pengaruh waktu aklimatisasi terhadap volatile suspended solid (VSS) dapat menurunkan kadar VSS selama mengalami proses saringan di dalam biosand filter dengan variasi perbandingan antara limbah cair laundry dengan nutrisi yakni 100\%:0, 75\%:25\% dan 50\%:50\% (dalam \% volume). Pada perbandingan 100\%:0 nilai volatile suspended solid (VSS) di hari ke-1 adalah 265,5 mg/l yang turun menjadi 96,82 mg/l di hari ke-30. Pada perbandingan $75 \%: 25 \%$ nilai volatile suspended solid (VSS) di hari ke-1 adalah 271,5 mg/l menurun menjadi 97,34 mg/l di hari ke-26. Begitu juga pada perbandingan 50\%:50\% dengan nilai volatile suspended solid (VSS) di hari ke-1 adalah 271,2 mg/l menurun menjadi 95,8 mg/l di hari ke26.

Pertumbuhan mikroba dapat dilihat dari nilai volatile suspended solid (VSS), pada penelitian nilai VSS pada cairan mengalami penurunan. Penurunan pada VSS di cairan tidak membuktikan bahwa tidak terjadi pertumbuhan mikroba atau pertumbuhan mikroba atau tidak pada tangki biosand filter. Untuk mengetahui terjadi pertumbuhan mikroba atau tidak pada tangki biosand filter dapat dilihat dari penurunan kandungan fosfat di dalam air limbah. Menurut teori, penurunan kadar fosfat dengan menggunakan cara biologi dengan memanfaatkan aktivitas mikroba dapat menurunkan kadar fosfat di dalam air limbah [2].

Penurunan nilai VSS dapat disebabkan tertahannya padatan atau partikel tersuspensi di pori-pori butiran pasir sehingga padatan atau partikel tidak mudah menerobos ke atas permukaan media pasir. Salah satu faktor yang berperan penting dalam menurunkan kandungan VSS di dalam air limbah adalah ketinggian media 
dalam proses penyaringan. Sehingga semakin tinggi media yang digunakan maka semakin tinggi pula penurunan nilai VSS. Faktor lain yang berperan penting dalam menurunkan kandungan VSS adalah penggunaan media yang digunakan karena fungsi dari media adalah sebagai tempat tumbuh dari mikroba [4].

\section{Profil Fosfat padaTangki Biosand Filter}

Fosfat dalam air limbah dapat berupa fosfat organik, orthophosphate anorganik atau sebagai fosfat kompleks. Fosfat organik juga dapat berasal dari bakteri atau tumbuhan penyerap fosfat [4]. Deterjen yang mengandung fosfat dapat menyebabkan stimulasi pertumbuhan tanaman dan surfaktan pada deterjen dapat bersifat toksik [2].

Pengaruh waktu aklimatisasi terhadap degradasi fosfat pada tangki biosand filter dapat dilihat pada gambar 4 .

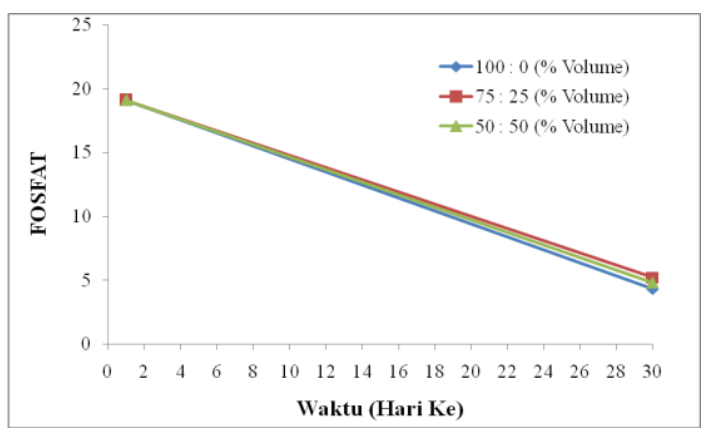

\section{Gambar 4. Pengaruh Waktu Terhadap Degradasi Fosfat Pada Biosand Filter}

Dari gambar 4 dapat dilihat, pengaruh waktu aklimatisasi dapat menurunkan kadar fosfat selama mengalami proses saringan di dalam biosand filter dengan variasi perbandingan antara limbah cair laundry dengan nutrisi yakni 100\%:0, 75\%:25\% dan 50\%:50\% (dalam \% volume). Pada perbandingan 100\%:0 nilai fosfat awal adalah 19,1 $\mathrm{mg} / \mathrm{l}$ menjadi $5,2 \mathrm{mg} / \mathrm{l}$ di hari ke-30. Pada perbandingan $75 \%: 25 \%$ nilai fosfat awal adalah $19,1 \mathrm{mg} / \mathrm{l}$ menjadi 4,8 mg//l di hari ke-26. Begitu juga pada perbandingan 50\%:50\% nilai fosfat awal adalah $19, \mathrm{mg} / \mathrm{l}$ menjadi $4,3 \mathrm{mg} / \mathrm{l}$ di hari ke-26.

Menurut teori, penurunan kadar fosfat dengan menggunakan cara biologi dengan memanfaatkan aktivitas mikroba dapat menurunkan kadar fosfat di dalam air limbah [2].

Bioreaktor dengan biakan melekat atau biofilter adalah reaktor yang dilengkapi dengan media (support) sebagai tempat pertumbuhan mikroorganimse, yang merupakan reaktor pertumbuhan melekat (attached growth reactor). Media penyangga dapat berupa kerikil, pasir, plastik dan partikel karbon aktif yang di dalam operasinya dapat terendam sebagian atau seluruhnya, atau hanya melewati air saja. Fungsi media adalah sebagai tempat tumbuh dan berkembangnya mikroorganisme yang terlibat langsung dalam pengolahan air limbah. Mikroorganisme ini akan melapisi permukaan media membentuk lapisan massa yang tipis yang disebut biofilm [16].

\section{KESIMPULAN}

Nilai $\mathrm{pH}, \mathrm{COD}$ dan volatile suspended solid (VSS) dan fosfat yang paling baik diturunkan oleh tangki biosand filter skala laboratorium adalah pada variasi perbandingan limbah cair laundry dan nutrisi 50\%:50\% yaitu pada $\mathrm{pH} \mathrm{7,1} \mathrm{dengan} \mathrm{nilai}$ COD awal $296 \mathrm{mg} / \mathrm{l}$ menjadi $105 \mathrm{mg} / \mathrm{l}$ dan nilai VSS awal adalah 271,2 mg/l menjadi $95,8 \mathrm{mg} / \mathrm{l}$ dengan penurunan fosfat sebesar 19,1 mg/l menjadi $4,3 \mathrm{mg} / \mathrm{l}$ maka percobaan oleh tangki biosand filter skala laboratorium sudah layak untung dikembangkan.

\section{DAFTAR PUSTAKA}

[1] Anggun, A. M. "Pengolahan Limbah dengan Media Biofilter Pasir", Tugas Akhir Teknik Lingkungan Semarang, Semarang, 2011.

[2] Connnell, D. W, and Miller, G. J. "Chemical and Acotoxicology of Pollution", John Wiley and Sons, Inc, New York, 1984.

[3] Hermansyah. "Teknologi Ultrafiltrasi dalam Pengolahan Limbah Laundry", Tugas Akhir Teknik Lingkungan Semarang, Teknik- Vol. 27 No. 2, 2010.

[4] Khusnuryani, Arifah. "Mikroba Sebagai Agen Penurun Fosfat pada Pengolahan Limbah Cair Rumah Sakit", Yogyakarta, Seminar Nasional Aplikasi Sains dan Teknologi IST AKPRIND, Yogyakarta, 2007.

[5] Kurniati, Elly. "Penurunan Konsentrasi Detergent Pada Limbah Industri Laundry Dengan Metode Pengendapan Menggunakan $\mathrm{Ca}(\mathrm{OH})_{2}$ ", Jurnal Ilmiah Teknik Lingkungan Vol. 1 No. 1, Surabaya, 2008.

[6] Mahlangu, Themba, O. dkk,. "A Simplified Cost-Effective Biosand Filter (BSFZ) for Removal of Chemical Contaminants from Water. Journal Departement of Chemical Technology, Journal University of Johannerburg, 2011.

[7] Murcrortt and Lucas, "Nepal Water Project :2001-2002, Journal Departement of Civil and Environmental Engineering Progman". Massachussetts Institute of Technology. 2002.

[8] Nasution, Satria. P. P, dkk,. "Pemulihan Kualitas Air Limbah Laundry dengan Reaktor". Tugas Akhir S1, Jurusan Teknik Lingkungan FTSP-ITS, Surabaya, 2013.

[9] Ngai, T. and Walewijk, S. "The Arsenic Biosand Filter $(A B F)$ Desaign of $A n$ 
Approriate Household Drinking Water Filter for Rural Nepal', Nepal, 2003.

[10] Peraturan Pemerintah Republik Indonesia Nomor 82 Tahun 2001. "Tentang PengolahanKualitas Air dan Pengendalian Pencemaran Air”. Jakarta, 14 Desember 2001 hal 1, 2001.

[11] Puspitahati, Cony dkk,. "Studi Kinerja Biosand Filter dalam Mengolah Limbah Laundry dengan Parameter Fosfat", Jurnal Jurusan Teknik Lingkungan FTSP-ITS, Surabaya, 2012.

[12] Rahayu, T, "Karakteristik Air Sumur Dangkal di Wilayah Kartasura dan Upaya Penjernihannya". Jurnal MIPA. Vol. 14, Hlm 40-51, 2004.

[13] S. Sukawati, T. "Penurunan Kadar Chemical Oxygen Demand (COD) pada Air Limbah Laundry Menggunakan Reaktor Biosand Filter dan Activated Carbon", Tugas Akhir Teknik Lingkungan Fakultas Teknik Sipil dan Perencanaan UII, Yogyakarta 2008.

[14] Shinta dan Prayatni, "Degradasi Biowaste Fasa Cair, Slurry, dan Padat dalam Reaktor Batch Anaerob Sebagai Bagian dari Mechanical Biological Treatment", Tugas Akhir Institut Teknologi Bandung, Bandung, 2005.

[15] Sopiah R. Nida, "Pengolahan Limbah Deterjen Sebagai Upaya Minimalisir Polutan di Badan Air dalam Rangka Pembangunan Berkelanjutan”, Balai Teknologi Lingkungan, Serpong, 1999.

[16] Sugiharto, "Dasar-Dasar Pengolahan Air Limbah", Jakarta: Universitas Indonesia 1987.

[17] Syafriadiman, Niken dan Saberina, "Prinsip Dasar Pengolahan Kualitas Air MM Press CV", Seminar Mina Mandiri, Pekanbaru, 2005.

[18] Utami, Anggi. Rizkia, "Pengolahan Limbah Cair Laundry dengan Menggunakan Biosand Filter dan Activated Carbon", Jurnal Teknik Sipil Untan/Volume 13 Nomor 1- Juni, Tanggerang 2013.

[19] Widyaningsih, Vini, "Pengolahan Limbah Cair Kantin Yongma Fisip Universitas Indonesia", Skripsi Fakultas Teknik Lingkungan, Universitas Indonesia, Jakarta, 2011. 